\title{
Tapping and Fostering Students' Emotional Intelligence through Service-learning Experiences
}

\author{
Susan L. Manring \\ Elon University
}

\begin{abstract}
Today's business students will chart their career paths through a rapidly changing, highly interdependent world of relationships and networks. In addition to traditional business school knowledge, students need cognitive, behavioral and affective skill sets, along with opportunities for civic engagement. This exploratory study of courseembedded service-learning, incorporating Cherniss and Goleman's emotional intelligence construct, found that students' service-learning experiences tapped and fostered the personal and social emotional intelligence competencies associated with professional effectiveness. Incorporating service-learning, with a focus on increasing emotional intelligence, offers a promising approach for business schools to reinforce and increase students' civic values as well as to enrich their personal and inter-personal emotional intelligence insights and skill development. This approach will strengthen the curricula and teaching practices of business schools to better prepare students for their roles as responsible leaders in creating and managing sustainable businesses and partnerships for our global-collective future.
\end{abstract}

\section{Introduction}

The Association to Advance Collegiate Schools of Business (AACSB, International) has stressed the critical role that business schools play in producing leaders who advance responsible and sustainable business worldwide. Further, business schools are increasingly expected to demonstrate how their missions, values, and societal roles anticipate and respond to the needs of multiple constituencies in a rapidly changing world (AACSB, 2008). Business educators are specifically challenged to create and promote course objectives which stress civic values, responsible business practices, and active engagements that are both local and global in an unpredictable but highly interdependent world (Papamarcos, 2005; Steiner \& Watson, 2006). Business students need cognitive, behavioral and affective skills to succeed in building collaborations through local and international relationships and networks in this largely unscripted global context (Clark, Callister, \& Wallace, 2003; Hilton, 2009; Whetten \& Cameron, 2007).

Service-learning, which is largely unscripted in practice, has become recognized as an effective pedagogical tool that enables faculty, students, and communities to reimagine societal roles for colleges and universities through the integration of their educational 
mission with active community engagement that is both local and international in scope (Enos \& Morton, 2001). Furthermore, service-learning is seen as a way of overcoming the limitations of the underlying paradigm of business education which views humanity and human interactions in purely transactional terms (Papamarcos, 2005), and the grounding morality of business education that asserts the supremacy of shareholder wealth (DiPadova-Stocks, 2005; Fairfield, 2010; Godfrey, Illes, \& Berry, 2005).

This study explores the use of academic service-learning projects in business school courses to further more holistic and integrated development of students' cognitive, behavioral and affective skills, including emotional intelligence awareness and competencies. The author's recognition of the potential to tap and foster emotional intelligence through academic service-learning projects was derived unexpectedly from a business student's reflective paper in an organizational behavior class. The student's assigned agency was the YMCA, and on his first visit, he apparently used a few inappropriate expletives. The director called him out and said either that language would have to stop immediately, or he would not be permitted to work at the YMCA. The student wrote,

I was in shock for a second but then it dawned upon me that the way I speak would definitely be frowned upon at many levels.... I had to watch my mouth extremely close, and choose my words with respect to the values of the YMCA.

What the student wrote (without any prompts from the teacher or any mention of emotional intelligence in the reflection assignment) reflected the four dimensions of emotional intelligence identified in Cherniss and Goleman's emotional intelligence construct: self-awareness and self-management; social awareness and relationship management (2001). At this point, the author realized the potential of service-learning to provide a co-curricular means of enabling students to tap into their emotional intelligence, and furthermore, that service-learning might also provide a stimulus to foster development of emotional intelligence.

\section{Emotional Intelligence Constructs}

Emotional intelligence theories and concepts reflect the growth of a relatively young field of inquiry, and there have been significant differences among researchers. For example, Locke (2005) found that the concept of emotional intelligence was a misinterpretation of the intelligence construct and should be referred to a skill. Landy (2005) summarized the issues related to research on emotional intelligence, including the criticism that emotional intelligence is a merging and conflagration of accepted but discrete concepts, definitions, and distinctions, (e.g., abilities, skills, attitudes, personality traits). Nevertheless, interest in emotional intelligence theories has continued to grow (Emmerling, Shanwal, \& Mandal, 2008). However, within the different streams of emotional intelligence research, disagreements remain about the definitions and models of emotional intelligence, how the term should be used, how emotional intelligence should be measured, and whether emotional intelligence can be learned and strengthened, or is an inborn characteristic. Caruso, Mayer, \& Salovey (2002) have 
differentiated two models of emotional intelligence: the Ability El model and the Mixed El model of competencies.

The Ability model defines emotional intelligence as four separate but related abilities: (1) the ability to accurately perceive one's own and others' emotions; (2) the ability to generate emotions to facilitate thought and action; (3) the ability to accurately understand the causes of emotions and the meanings they convey; and (4) the ability to regulate one's emotions (Daus \& Ashkanasy, 2005; Mayer, Salovey, \& Caruso, 2008). The Ability model assumes that just as people differ on practical intelligence, so do they differ on their ability to perceive and regulate emotions. This differentiation allows researchers to determine if emotional intelligence is a separate ability that can predict effectiveness over and beyond cognitive abilities (Mayer et al. 2008).

The Mixed model of emotional intelligence competencies (Goleman, 1998) incorporated the abilities discussed above (perceiving, managing, using, and understanding emotions), and also included a number of other competencies subsumed within five major abilities: Self-Awareness, Self-Regulation, Motivation, Empathy, and Social Skills. Cherniss and Goleman's more recent construct has consolidated the competencies as four dimensions: Self-Awareness, Self-Management, Social Awareness, and Relationship Management (2001). In this Mixed model, each dimension of emotional intelligence is comprised of several competencies, and the 20 competencies, in total, provide a broad definition of emotional intelligence.

The importance of emotional intelligence has been recognized as a vital part of the educational process for well over a decade (Elias, Zins, \& Weissberg,1997; Stuller, 1997). One variation or another of emotional intelligence appears as a topic now in virtually every management and leadership textbook. Advocates of both the emotional intelligence and management skills movements maintain that intrapersonal and interpersonal skills are critical success factors and cannot be substituted with cognitive intelligence or technical skills (Cherniss \& Goleman, 2001; Clark, et al., 2003; Goleman, 1998; Whetten \& Cameron, 2007).

Keating, Rishel, \& Byles (2005) offered several suggestions for introducing emotional intelligence into the business curriculum, and a number of management skills courses have been used successfully to improve students' emotional intelligence scores (Brown, 2003; Burbach, 2008; Clark et al. 2003). Emotional intelligence skills have been recognized as essential components of graduate management education (Boyatzis, Stubbs, \& Taylor, 2002), and related work has sought to investigate linkages between emotional intelligence and leadership in training and teaching contexts (Ashkanasy \& Dasborough, 2003; McCambridge, McCarthy, \& Tucker, 2000; Rhee \& Sigler, 2010). Clark et al. (2003) have noted that for management education particularly: "Skills such as motivation, empathy, and team building can work synergistically with intelligence and technical skills to produce the highest level of performance within organizations" (p. 4). Business organizations value having more emotionally intelligent employees and are trying to teach these skills to current employees (Ashkanasy \& Daus, 2002, 2005; Jordan, Ashkanasy, \& Hartel, 2002; McCarthy, 2000). To this end, counselors have 
focused on development of emotional intelligence competencies to help college students succeed in the workplace (Liptak, 2005).

\section{Co-Curricular Contributions of Service-learning}

Viewing course-embedded service-learning in the context of experiential education across university curricula is not a new concept - in fact, the history of this movement dates back to the late 1960s. Academic service-learning emphasizes close connections to course learning objectives, as well as equal benefits received by both students and clients (Sharifi, McCombs, \& Kattelus, 2003). Educators, community leaders, and students have articulated a threefold rationale for combining traditional classroom pedagogies with community service: (1) this combination leads to more effective teaching and learning; (2) it facilitates effective collaborations between the campus and the community; and (3) it helps to prepare students for more effective participation as citizens and professionals in the communities in which they will work and lead their lives (Campus Compact, 2003; Checkoway, 2001; Buchanan, Baldwin, \& Rudisill, 2002; Jacoby, 1996; Kenworthy-U'Ren, 2008; Kupiec, 1993; Lester, Tomkovick, Wells, \& Flunker, 2005).

Only within the last fifteen years have educators reported on efforts to integrate academic service-learning into business school curricula (Collins, 1996; Driscoll, Holland, Gelmon, \& Kerrigan, 1996; Kolenko, Porter, Wheatley, \& Colby, 1996; Liu, 1995; Rama, 1998; Trent, Grasso, \& Roby, 1996; Zlotkowski, 1996). These efforts have been well documented in The American Association for Higher Education series on service-learning in the disciplines (Godfrey \& Grasso, 2000). More current concepts and models for incorporating service-learning into business school education, include management, leadership, human resource management, marketing, information systems, accounting, and the MBA curricula (Andrews, 2007; Godfrey et al. 2005; Keating et al. 2005; Papamarcos, 2005; Salimbene, Buono, LaFarge, \& Nurick, 2005; Sharifi et al. 2003). Steiner \& Watson (2006) have emphasized that for service learning to be an effective component of business education, it cannot be treated as one among many assignments; course objectives must emphasize civic responsibility and community involvement.

Despite the inherent links between emotions and intellect in the process of learning from experience (Felten, Gilchrist, \& Darby, 2006), and the potentially inherent value of using service-learning and civic engagement to foster emotional intelligence, reviews of college/university pedagogical literature, and business school education literature, in particular, reveal no published results to date that examine service-learning in relation to emotional intelligence competencies. Historically, in fact, both service-learning research and practice have been molded primarily by the inattention to emotion. For example, the Michigan Journal of Community Service Learning's special issue on strategic directions for service-learning research (Howard, 2000) virtually ignores emotion as a consideration in any aspect of the field's research. Felten et al. (2006) have called for a reorientation of approach that acknowledges the continuous interplay between the intellectual and the emotional throughout active learning experiences. Such a 
reorientation of approach would incorporate both the personal and social dimensions of emotional intelligence (Cherniss \& Goleman, 2011) that come into play with academic service-learning. Furthermore, these dimensions of emotional intelligence are consistent with the four components of academic service-learning (Cohen, 1994; Godfrey \& Grasso, 2000):

1. Students actively participate in organized service experiences that meet actual community needs and that are coordinated in collaboration with the school and community.

2. These experiences are integrated into the students' academic curriculum, and/or structured time is provided for them to think, talk, or write about what they did and saw during their actual service activity.

3. Students have opportunities to use newly acquired skills and knowledge in real-life situations in their own communities.

4. These experiences help to foster the development of a sense of caring for others.

\section{Action Research Methodology and Research Questions}

Building on the interplay between intellectual and emotional learning, this study was undertaken as an action research project to explore and describe connections between academic service-learning and emotional intelligence competencies so as to improve teaching practices (Carr \& Kemmis, 1986; Ellis \& Kiely, 2000; McNiff, 2002; Reason \& Bradbury, 2007). The operational premises of this study were: (1) emotional intelligence is a useful and integrative (mixed) construct; (2) dimensions of emotional intelligence are inborn trait characteristics; and (3) emotional intelligence abilities and competencies can also be learned and strengthened.

The study incorporated Cherniss and Goleman's emotional intelligence construct (2001) to explore the following questions: (1) Would students discover that their servicelearning experiences tapped and fostered emotional intelligence competencies? (2) Would service-learning projects enhance students' awareness of the need to express and behave with emotional intelligence? (3) Would students make these connections naturally and on their own? (4) And, if solid connections were found, would incorporating service-learning into the business school curriculum improve practice through these complementary means for facilitating civic engagement and holistic student development that is cognitive, behavioral and affective?

\section{Methods}

\section{Participating Students and Organizations}

Over the course of several semesters, 140 undergraduate students majoring in management participated in upper level academic service-learning management major electives, including two leadership courses and five organizational behavior classes. While some students in the different classes would most likely have known each other, 
the courses were run entirely separately. During the semesters of this study, none of the students were in more than one of these classes.

The students were randomly assigned in small groups to non-profit agencies including: The Women's Resource Center, Meals on Wheels, an assisted living/retirement home, a senior center, a foodbank, a housing authority after-school enrichment program, the Boys and Girls Club, AlaMap (providing medications for those who can't afford them), and the YMCA. The placements involved direct contact with the clients whom the agencies served, e.g., women, children, families, and the elderly.

\section{Procedures and Assignments}

Students were each expected to serve at least 15 hours in their assigned organization, which our university considers an effective minimum. Assignments tied the course material to the academic service-learning experience. In the leadership classes, in addition to giving 15 hours of service to their agencies, students conducted group interviews with the agency directors. Their written interviews were graded for demonstrated cognitive skills and learning in developing well-structured, in-depth interviews about leadership-in-practice. In the organizational behavior classes, in addition to giving 15 hours of service, students gathered data and analyzed their assigned agencies, focusing on elements of individual behavior, group behavior, organizational processes, and organizational strategy, structure, and environment; they were also required to develop a recommended change plan for their agency. In some classes, agency directors attended a class session and worked further on their action plans with their assigned students. In addition, the directors of our university servicelearning center frequently attended the presentations and asked for the students' papers, to be used in their ongoing development work with agencies.

As a follow-up activity to the academic component of their service-learning experience, students were asked to write about their individual insights and reflections. The reflective papers gave students an open, unstructured way to consider what their service-learning experiences had meant to them. Care was taken with the reflection assignment not to lead students by any direct or indirect mentioning of emotional intelligence, nor to mention any potential connections between service-learning and emotional intelligence. Since the intention of this exploratory study was to determine whether students, on their own, would find connections between service learning and emotional intelligence, the reflective assignment was unstructured in order to gauge the natural emergence and inherent potency of dimensions of emotional intelligence in selfinitiated, non-directed reflections about service-learning.

\section{Content Analysis and Coding of Students' Reflective Papers}

The service-learning reflection papers were subjected to a content analysis of emotional intelligence (EI) themes, according to the competencies identified in Cherniss and Goleman's emotional intelligence construct (2001). The researcher repeated the analysis and coding of all papers three months later to determine rating reliability. $A$ 
third analysis and coding of a random sampling of students' statements, conducted by a colleague not involved in the study, established $90 \%$ co-rater reliability. Some students provided more than one comment, each of which reflected a different El competency. Care was taken to ensure that only one comment per student was coded and counted for each competency.

\section{Results}

Table 1 shows that a total of 256 statements from 140 students, reflecting all $20 \mathrm{El}$ competencies, were used in the content analysis and coding process.

Table 1

Service-Learning Reflections Codified as Dimensions of Emotional Intelligence* (Cherniss \& Goleman, 2001)

\begin{tabular}{|c|c|}
\hline Self (Personal Competence) & Other (Social Competence) \\
\hline $\begin{array}{l}\text { Self-Awareness (71 Comments) } \\
\text { - Emotional self-awareness (25) } \\
\text { - Accurate self-assessment (29) } \\
\text { - Self-confidence (17) }\end{array}$ & $\begin{array}{l}\text { Social Awareness (110 Comments) } \\
\text { - Empathy (22) } \\
\text { - Service orientation (58) } \\
\text { - Organizational awareness (30) }\end{array}$ \\
\hline $\begin{array}{l}\text { Self-Management (28 Comments) } \\
\text { - Emotional self-control (11) } \\
\text { - Trustworthiness (4) } \\
\text { - Conscientiousness (3) } \\
\text { - Adaptability (6) } \\
\text { - Achievement drive (1) } \\
\text { - Initiative (3) }\end{array}$ & $\begin{array}{l}\text { Relationship Management (47 Comments) } \\
\text { - Developing others (10) } \\
\text { - Influence (6) } \\
\text { - Communication (3) } \\
\text { - Conflict management (1) } \\
\text { - Casionary leadership (6) } \\
\text { - } \text { Building bonds (5) } \\
\text { - Teamwork and collaboration (14) }\end{array}$ \\
\hline
\end{tabular}

* Note: The aggregate numbers in Table 1, shown within each of the four dimensions of emotional intelligence, e.g., Self-Awareness (71), indicate coded comments, not the number of students; i.e., an individual student's reflective paper often included statements about more than one emotional intelligence competency, and the statements were coded accordingly. A student's comment was only counted once within each competency, i.e., the 25 comments about the "Emotional Self-Awareness" competency represent 25 different students; however, some of those 25 students may have contributed to the 29 comments about the "Accurate Self-Assessment" competency.

As shown in Table 1, nine individual emotional intelligence competencies were mentioned in at least ten students' responses and in as many as 58 students' responses:

$\begin{array}{ll}- & \text { Service orientation (58) } \\ - & \text { Organizational awareness (30) } \\ - & \text { Accurate self-assessment (29) }\end{array}$




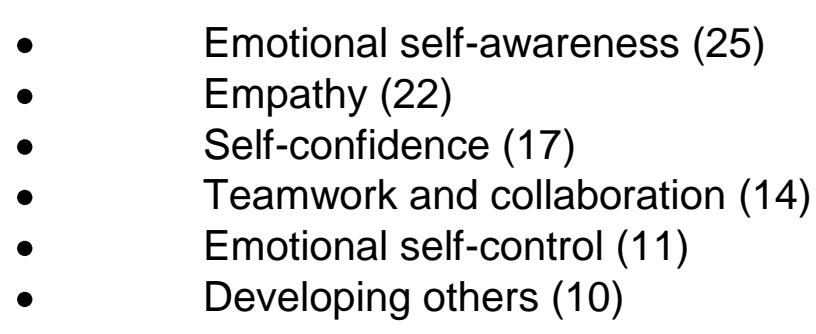

Overall, the greatest number of coded statements reflected dimensions of Social Awareness (110 comments). One specific aspect of Social Awareness, "Service Orientation", was reflected by more students' statements (58) than by any other emotional intelligence competency. This was an important finding: enabling students to actively experience themselves being of service to others is a powerful way to tap into their personal and interpersonal emotional awareness. Without prompts from the teacher or mention of emotional intelligence in the reflection assignment rubric, one student wrote,

This ended up being one of the better experiences of my whole four years at the university. Nothing that is happening here at college is really going to have that great an everlasting effect on my life. For the first time, I really felt like I helped out the larger community and got something in return. I wish I had worked with organizations such as this earlier. My experience with the youth put my life situation into perspective.

Service-learning experiences which are mutually beneficial to agencies, their clients, and students, provide a way to shift students out of their natural young adult narcissism toward a fuller sense of self in the service of others - what McCarthy and Tucker (2002) call "an empathic feeling of moral obligation" (p. 645).

The following quotations, taken from the coding of the most frequently mentioned SelfAwareness and Social Awareness El competencies in Table 1, were chosen for being particularly illustrative of dimensions of emotional intelligence most often tapped and fostered by students' service-learning experiences. The definition of each dimension is drawn from Cherniss and Goleman (2001).

\section{$\underline{\text { Self-Awareness }}$}

Emotional self-awareness - recognizing one's own feelings and how they affect one's behavior:

- I chose to work with the food pantry because I wanted to step outside my comfort zone...I am embarrassed to say that I was a little surprised and scared to be around hungry people.

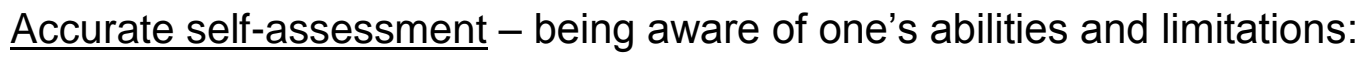


- ...Unfortunately, I fell back on this assumption of expecting rude, ungrateful people when I went to the agency, yet everyone was extremely friendly and appreciative. This experience made me realize once again...that in order to truly get to know and understand someone, you must talk to them and know their background because appearances will not tell you anything.

Self-confidence - being confident of one's capabilities in different situations:

- The more I went, the more comfortable I became with the kids and the employees. I developed personal relationships with many of them, which I think made them feel as though they could ask me for help and trust me. I felt good about being a good role model for the kids.

\section{$\underline{\text { Social Awareness }}$}

Empathy - an awareness of others' emotions, concerns, and needs:

- I learned it is very important when dealing with the needy (at the food bank) to be respectful and considerate because they are people with families, too, and often can feel embarrassed due to their circumstances.

Service orientation - being able to identify another's often unstated needs and concerns and then providing appropriate goods and/or services:

- I would have been the last person to ever accept that helping out at a non-profit organization that gives food to the needy would have changed how I look at my future plans. However, everything in life is a chance for you to learn something for the future, and I did learn something by volunteering at the food bank. I learned how important it is to help people in any way that you can.

Organizational awareness - the ability to read group and organizational-level needs and capabilities, as well as emotional and political situations objectively:

- My experience at the center was so much more rewarding than I ever believed it would be. I was able to help children each time I gave my time and had an opportunity to see how concern for employees' feelings and needs can be important in an organization. I have learned that success and production are not always measured in a dollar amount. People are the key to a successful organization, and must be treated as individuals through reliable and responsible leadership. 


\section{Discussion}

The Natural Interplay between Emotional Intelligence and Service-learning

This study answered our first research question by demonstrating the ways in which service-learning experiences tap and foster emotional intelligence competencies. We found, in answer to our second research question, that service-learning projects enhance students' awareness of the need to express and behave with emotional intelligence. One unsolicited student reflection illustrates how this awareness was enhanced by the need for emotional self-control. The student wrote "I do not know of anyone that could work in this learning center for disabled children and not grow emotionally. I had to be in tune with their emotions and not worry so much about my own emotions."

Consistent with the work of Sharifi et al. (2003), this study found that service-learning experiences are transformed into students' learnings, including insights about their emotions and behavior. Furthermore, in answer to our third research question, would students make these connections naturally and on their own, this study demonstrates that processes of reflection about service-learning experiences naturally include insights about students' emotions and behavior. Even when the connection was not solicited, a student noted the development of empathy: "It was difficult for me to connect and be comfortable around the developmentally disabled, but then I warmed up and found myself feeling very comfortable and empathetic." Another student found personal limitations through an accurate self-assessment: "To my surprise, I felt uncomfortable at the nursing home. I learned that it takes special people to work at nursing homes day in and day out. I do not know if I have the emotional stability to do that."

This finding of the natural connections between emotional intelligence and servicelearning has implications for service-learning research, as well as for business school education. Felten et al. (2006) noted that service-learning research and practice, in general, has tended to focus on intellectual thinking as a higher order response than the emotional. Acknowledging the importance of the natural interplay of emotion and cognition, they proposed an integration of emotion into the service-learning literature; further, they suggested that this re-definition should lead to new practices in servicelearning pedagogy. Although these practices may be new to some, the changes might not be so very great for some faculty and students. Similar to the findings in this study, earlier work by Eyler, Giles, \& Schmiede (1996) determined that some students naturally bring together intellect and emotion throughout the service-learning reflective process.

\section{The Emotive and Unpredictable Contexts of Service-learning}

What makes service-learning so effective as a vehicle for both the expression and development of emotional intelligence is that the context (especially nonprofit social service agencies) moves students out of their comfort zone. Service-learning, in practice, is unpredictable; students are thrust into novel situations and must learn 
experientially how to adapt and respond to what are often non-programmed situations, requiring both intrapersonal and interpersonal emotional intelligence. As one student wrote, "I learned to step outside my comfort zone in order to have new experiences. I learned patience, tolerance, and the ability to block too much emotional involvement."

Exposure to people whose life circumstances were more difficult and challenging than those of our students awakened for many a sense of appreciation for what they had, as well as a kind of awareness of vulnerability ("But for fate, there walk I ..."), and that life can be hard and do hard things to people. Hence, a key principle in using servicelearning as a means to tap and foster emotional intelligence is that the more the experiences move students' focus from their heads to their hearts, i.e., the richer the emotive and unscripted context of the experiences, the deeper the students' reflections and learning about emotional intelligence. For example, students who worked with clients in a women's resource center, an after-school day care program, a foodbank, and an eldercare facility, reflected more learning about their emotional intelligence than those whose primary exposure to a social service agency was through attending board meetings.

\section{The Quality of Reciprocity}

As the students' reflections in this study indicate, academic service-learning provides a real-life context for stimulating students' emotional intelligence. In large part it is the quality of reciprocity - the emphasis on equal benefits for students and clients - that enhances the development and expression of students' emotional intelligence, as they both give to and receive from the experience. As a student wrote, without any prompts:

Being a volunteer at the senior home made me feel good about myself because making a meaningful difference in the lives of others is gratifying.... It felt good to know that I had given up time in order to help others battle loneliness and boredom. I am a family oriented individual and I felt that this experience correlated with my own values and beliefs. I liked knowing that I was helping to bring meaning to the life of someone's mother, grandmother, father, or grandfather.

\section{The Cognitive and Affective Engagement with Civic Issues}

Our fourth research question asked: if solid connections were found between emotional intelligence and service-learning, would incorporating service-learning into the business school curriculum improve practice through these complementary means for facilitating civic engagement and holistic student development that is cognitive, behavioral and affective?

We found that the answer is yes, and this is another important connection between service learning and emotional intelligence: service-learning provides timely, provocative, and affectively-rich means for students to connect cognitively and emotionally to current issues that impact multiple stakeholders in ways that are 
increasingly unpredictable (Lester et al. 2005). For example, our organizational behavior students working at the local food bank learned there was less food available because local farmers were selling fruit and vegetable remainders in their fields as bio-fuel stock rather than giving the remainders to the food bank. This, in turn, created shortages for the after-school program where other students were working because the after-school snacks were provided by the food bank. These were not merely cognitive learnings for the students. The experiences touched their emotional intelligence (social awareness and relationship management) as well because they packed and delivered the food bags and the after-school snacks to the families and children they were getting to know. In the students' exploration of these issues, they linked their service-learning experiences to questions about corporate social responsibility in relation to shareholder wealth, e.g., the economics of bio-fuels vs. food, and sustainable business development for sustainable communities. Because of their service-learning experiences, they didn't simply think about these issues academically. They cared about the issues, and they felt the economic impacts on our local community. One student wrote:

Overall I think that our service learning experience was a positive one. It made our group stand back and reflect on how truly blessed we are, and how easily our lives could have been unimaginably different than they are today. Visiting these people and seeing, even for a few minutes, how they live each and every day drove home just what kind of a caring environment our university community truly is, in comparison. After this experience - for many in our group - I believe that the "university bubble" took on an entirely new meaning that it never had before.

\section{The Affective Reinforcements of Service-learning}

Clark et al. (2003) indicated that there is "no definitive evidence that the effects of increased emotional intelligence will last" (p. 19). Similarly, according to Boyatzis and Saatcioglu (2008), emotional and social development can be eroded without continuous improvement and renewal. Local or international service-learning as a component of management education may provide the extra stimulus that reinforces students' learning. The acronym "WE CARE" represents the principles that are essential to successful service-learning: "welcomed, evidence-based, complementary, actionoriented, reciprocal, and epistemic" (Kenworthy-U'Ren \& Peterson, 2005, p. 272). In particular, the epistemic nature of service-learning, which is very context dependent, provides students with experiences that stimulate integrative cognitive, behavioral and affective processing. Furthermore, this interplay between intellectual and emotional reflections reinforces the deeper service-learning experiences called for in the servicelearning literature (Felten et al. 2006), and impacts students' behaviors in powerful ways that are not easily forgotten. Two students' comments, written without prompts, are especially illustrative of how contextually specific service-learning experiences may linger more vividly as a values-based plumb-line in students' affective memories:

I am extremely grateful for my opportunity to volunteer with the food bank. Over the past year, I have found myself wishing my family was wealthier and when I look back at that, I am extremely ashamed. Never can I recall a time when my 
family did not have enough money to buy food or any other necessities. I would not trade my time spent at my service learning agency for anything. I built strong relationships which will not be forgotten and at the same time I have gained a strong sense of self-understanding.

Whenever I was having a bad day, I knew that I could work for a few hours with the children at the after school program. Nothing that is happening here at college is really going to have that great an everlasting effect on my life. I say this now, and I hope that someday I will be able to back this statement up, but when I make enough money to support myself and my family, I want to give back to these kids.

\section{Conclusions}

This exploratory study demonstrates that service-learning experiences in one-semester courses can evoke significant insights, learning, and gains regarding emotionally intelligent awareness and behaviors. Using the students' own language, the significance of this qualitative study lies in the self-revelations provided in reflective papers that were written without students having been coached or prompted to comment on emotional intelligence. Three forces: increased awareness of different people in different life circumstances, a glimpse of an "other-centered" self-definition, and a preview of one's vulnerability - along with self-reflective processes - are key service-learning elements that help students tap into their emotional intelligence and to foster further development of emotional intelligence competencies. While all 20 of the emotional intelligence competencies identified by Cherniss and Goleman (2001) were found and coded in the students' service-learning reflective papers (Table 1), the emotional intelligence competencies most frequently mentioned by the students are among the personal and social skills that lead to effective performance in the work world: emotional selfawareness, accurate self-assessment, self-confidence, emotional self-control, empathy, service orientation, organizational awareness, developing others, and teamwork and collaboration. Regardless of their career paths, business students today need to be prepared for involvement in global business relationships and networks. In addition to traditional business school knowledge, skills and abilities, students will need emotional intelligence competencies as they mature into responsible global business managers and leaders and chart their paths through a rapidly changing, highly interdependent world (Hilton, 2009).

The primary emphasis in business schools is on developing personal competencies, and business students typically focus primarily on two societal roles: consumers and investors. Responsible business leadership also includes social and values-based competencies, expressed through civic engagement and citizenship. The unique contribution of service-learning to the business curriculum is that it reinforces the importance of civic engagement and local as well as global citizenship (Steiner \& Watson, 2006). Service-learning experiences may awaken or re-awaken students' deeply-felt values about their inter-related role(s) in society. As one student wrote, 
This situation touched upon my own values very directly. My religious teachings taught me to be humble by learning to serve, touch, and help the lives of others. This experience triggered all these emotions once again, something I haven't felt or been subjected to since my high school days. It was extremely gratifying to touch upon my own deeply felt values once again.

Keating et al. (2005) asked the question: "If an understanding of emotion and emotional management is critical for business success, what role should universities play in this process, particularly at the undergraduate level?" (p. 57). This question remains a very important one to ask of college and university educators as we consider the future roles of higher education. Business educators are expected to develop curricula for students that focus on developing collaboration skills and building strategic alliances.

Incorporating active local and international community engagements through servicelearning, with a focus on increasing emotional intelligence, offers a very promising approach for business schools to reinforce and increase students' civic values as well as to enrich their personal and inter-personal emotional intelligence insights and skill development. This approach will strengthen the curricula of business schools to better prepare students for their roles as responsible leaders in creating and managing sustainable businesses and partnerships for our global-collective future.

\section{Recommendations}

More action research on teaching practices is needed to examine the service-learning and emotional intelligence interface for promoting civic engagement and holistic student development, to develop pedagogies that strengthen these linkages, and to intentionally incorporate emotional intelligence learning strategies within course-based servicelearning. Other studies could further explore coupling service-learning with the fostering of students' emotional intelligence competencies as an effective means to address the limitations of traditional business school curricula. These studies would also further service-learning research and practice.

Longitudinal studies spanning more than a semester and requiring more than 15 service hours are needed to obtain meaningful quantitative data. However, the limitation of a questionnaire, noted by Clark, et al. (2003), is that it is not an actual measurement of emotionally intelligent behavior; it is a gauge of students' beliefs about their behavior, measured rather abstractly.

Research involving international service-learning experiences would be very valuable. Potentially, international service-learning experiences could amplify the call for students to deepen their emotional intelligence as they learned how to respond to nonprogrammed cross-cultural situations. Fruitful next steps would be designing both local and international academic service-learning courses to intentionally foster emotional intelligence competencies and to heighten cognitive and affective experiences of citizenship in vivid ways that positively influence students' responsible business and civic roles in an unscripted, unpredictable and highly interdependent world. 


\section{References}

Andrews, C. P. (2007). Service Learning: Applications and research in business. Journal of Education for Business, 83(1), 19-26.

Ashkanasy, N. M., \& Dasborough, M. T. (2003). Emotional awareness and emotional intelligence in leadership teaching. Journal of Education for Business, 79(1),1824.

Ashkanasy, N. M., \& Daus, C. S. (2002). Emotion in the workplace: The new challenge for managers. Academy of Management Executive, 16(1), 76-86.

Ashkanasy, N. M., \& Daus, C. S. (2005). Rumors of the death of emotional intelligence in organizational behavior are vastly exaggerated. Journal of Organizational Behavior, 26(4), 441-452.

Association to Advance Collegiate Schools of Business, AACSB, International 20072008 Conferences. Retrieved from http://www. aacsb. edu/conferences/

Boyatzis, R. E., Stubbs, E. C., \& Taylor, S. N. (2002). Learning cognitive and emotional intelligence competencies through graduate management education, Academy of Management Journal on Learning and Education, 1(2), 150-162.

Boyatzis, R. E., and Saatcioglu, A. (2008). A 20 -year view of trying to develop emotional, social and cognitive intelligence competencies in graduate management education. Journal of Management Development, 27(1), 92-108.

Brown, R. B. (2003). Emotions and behavior: Exercises in emotional intelligence. Journal of Management Education, 27(1), 122-134.

Buchanan, A. M., Baldwin, S. C., \& Rudisill, M. E. (2002). Service learning as scholarship in teacher education. Educational Researcher, 31(8), 30-36.

Burbach, M. E. (2008). Emotional intelligence in professional and personal settings: An experiential learning exercise. Journal of the Academy of Business Education, 9, 98-110.

Campus Compact. (2003). Introduction to service-learning toolkit: Readings and resources for faculty. $2^{\text {nd }}$ ed. Providence, Rl: Brown University.

Carr, W., \& Kemmis, S. (1986). Becoming critical: Education, knowledge, and action research. New York, NY: RoutledgeFarmer.

Caruso, D. R., Mayer, J. D., \& Salovey, P. (2002). Emotional intelligence and emotional leadership. In R. E. Riggio, S. E. Murphy, \& F. J. Pirozzolo (Eds.), Multiple Intelligences and Leadership (pp. 55-74). Mahwah, NJ: Lawrence Erlbaum Associates.

Checkoway, G. (2001). Renewing the civic mission of the American research university. Journal of Higher Education, 72(2), 125.

Cherniss, C., \& Goleman D., (Eds.). (2001). The emotionally intelligent workplace: How to select for, measure, and improve emotional intelligence in individuals, groups, and organizations (p. 28). New York, NY: Jossey-Bass.

Clark, S. C., Callister, R., \& Wallace, R. (2003). Undergraduate management skills courses and students' emotional intelligence. Journal of Management Education, $27(1), 3-23$.

Cohen, J. (1994). Matching university mission with service motivation: Do the accomplishments of community service match the claims? Michigan Journal of Community Service Learning, 1(1), 98-104. 
Collins, D. (1996). Closing the gap between business students and the poor: Journal of Business Ethics, 15(1), 1-4.

Daus, C. S., \& Ashkanasy, N. M. (2005) The case for the ability-based model of emotional intelligence in organizational behavior. Journal of Organizational Behavior, 26(4), 453-466.

DiPadova-Stocks, L. N. (2005). Two major concerns about service-learning: What if we don't do it? And what if we do? Academy of Management Learning \& Education, 4(3), 345-353.

Driscoll, A., Holland, B., Gelmon, S., \& Kerrigan, S. (1996). An Assessment model for service-learning: Comprehensive case studies on impact on faculty, students, community and institution. Michigan Journal of Community Service, 3(1), 55-65.

Elias, J. J., Zins, J. E., \& Weissberg, R. P. (1997). Promoting social and emotional learning: Guidelines for educators. Alexandria, VA: Association for Supervision and Curriculum Development.

Ellis, J. H. M., \& Kiely, J. A. (2000) Action inquiry strategies: Taking stock and moving forward. Journal of Applied Management Studies, 9(1), pp. 83-94.

Emmerling, R. J., Shanwal, V. K., \& Mandal, M. K. (Eds. ). 2008). Emotional Intelligence: Theoretical and Cultural Perspectives. Hauppauge, NY: Nova Science Publishers.

Enos, S., \& Morton, K. (2002). Developing a theory and practice of campus-community partnerships, in B. Jacoby (Ed.), Developing and Practice of CampusCommunity Partnerships in Building Partnerships for Service-Learning (pp. 2041). San Francisco, CA: Jossey-Bass.

Eyler, J., Giles, D. E. Jr., \& Schmiede, A. (1996). A practitioner's guide to reflection in service learning: Student voices \& reflections. Nashville, TN: Vanderbilt University.

Fairfield, K. D. (2010). Growing up and growing out: Emerging adults learn management through service-learning. Journal of Management Education, 34(1), 113-141.

Felten, P., Gilchrist, L., \& Darby, A. (2006). Emotions and learning: Feeling our way toward a new theory of reflection in service-learning. Michigan Journal of Community and Service-Learning, 122, 38-46.

Godfrey, P. C., \& Grasso, E. T. (Eds. ) (2000). Working for the common good: Concepts and models for service-learning in management. Washington, D. C.: American Association for Higher Education.

Godfrey, P. C., Illes, L. M., \& Berry, G. R. (2005). Creating breadth in business education through service-learning. Academy of Management Learning \& Education, 4(3), 309-323.

Goleman, D. (1998). Working with Emotional Intelligence. New York, NY: Bantam.

Hilton, M. (2009). Skills for work in the $21^{\text {st }}$ century: What does the research tell us? Academy of Management Perspectives, 22(4), 63-78.

Howard, J. (Ed.). (2000, Special Issue). Strategic directions for service-learning research. Michigan Journal of Community Service Learning, 7(1).

Jacoby, B. (1996). Service learning in today's higher education. In B. Jacoby and Associates, (Eds.), Service-Learning in Higher Education: Concepts and practices (pp. 3-25). San Francisco, CA: Jossey-Bass. 
Jordan, P., Ashkanasy, N. M., \& Hartel, C. (2002). Emotional intelligence as a moderator of emotional and behavioral reactions to job insecurity. Academy of Management Review, 27(3), 361-372.

Keating, R. J., Rishel, T. D., \& Byles, C. M, (2005, Fall). Mission impossible? The challenges of incorporating emotional intelligence and emotional competence into an undergraduate business curriculum. Journal of the Academy of Business Education, 6, 50-63.

Kenworthy-U'Ren, A. L., \& Peterson, T. O., (2005). Introducing the WE CARE approach. Academy of Management Learning \& Education. 4(3), 272-277.

Kenworthy-U'ren, A. L. (2008). A decade of service-learning: A review of the field ten years after JOBE's seminal special issue. Journal of Business Ethics, 81(4), 811822.

Kolenko, T., Porter, G., Wheatley, W., \& Colby, M. (1996). A critique of service-learning projects in management education: Pedagogical foundations, barriers, and guidelines. Journal of Business Ethics, 15(1), 133-142.

Kupiec, T. Y. (Ed.) (1993). Rethinking tradition: Integrating service with academic study on college campuses. (Denver, CO: Education Commission of the States/Campus Compact).

Landy, F. J. (2005). Some historical and scientific issues related to research on emotional intelligence. Journal of Organizational Behavior, 26, 411-424.

Lester, S. W., Tomkovick, C., Wells, T., \& Flunker, L. (2005). Does service-learning add value? Examining the perspectives of multiple stakeholders. Academy of Management Learning \& Education, 4(3), 278-294.

Liptak, J. J. (2005). Using emotional intelligence to help college students succeed in the workplace. Journal of Employment Counseling, 42, 171-178.

Liu, G. (1995). Knowledge, foundations, and discourse: Philosophical support for service-learning. Michigan Journal of Community Service Learning, 2(1), 5-18.

Locke, E. A. (2005). Why emotional intelligence is an invalid concept. Journal of Organizational Behavior, 26, 425-431.

Mayer, J. D., Salovey, P., \& Caruso, D. R. (2008). Emotional Intelligence: New ability or eclectic traits. American Psychologist, 63(6), 503-517.

McCambridge, J., McCarthy, A. M., \& Tucker, M. L. (2000). An empirical investigation of the linkages between emotional intelligence and leadership in a training context. Journal of Contemporary Business Issues, 8(2), 55-62.

McCarthy, A. M., \& Tucker, M. L. (2002). Encouraging community service through service learning. Journal of Management Education, 26(6), 629-647.

McNiff, J. 2002). Action research: Principles and practice. New York, NY: RoutledgeFalmer.

Papamarcos, S. D. (2005). Giving traction to management theory: Today's servicelearning. Academy of Management Learning \& Education, 4(3), 325-335.

Rama, D. V. (Ed.) (1998). Learning by doing. Concepts and models for service-learning in accounting. Washington, D. C.: American Association for Higher Education and the KPG Peat Marwick Foundation.

Reason, P., \& Bradbury, H. (2007). The SAGE handbook of action research: Participative inquiry and practice. London: Sage. 
Rhee, K. S., \& Sigler, T. (2010). Developing enlightened leaders for industry and community: Executive education and service learning. Journal of Management Education, 34(1), 163-181.

Salimbene, F. P., Buono, A. F., LaFarge, V. V. S., \& Nurick, A. J. (2005). Servicelearning and management education: The Bentley experience. Academy of Management Learning \& Education, 4(3), 336-344.

Sharifi, M., McCombs, G. B., \& Kattelus, S. C. (2003, Spring). Using service-learning to develop competencies in a capstone accounting course. Journal of the Academy of Business Education, 89-100.

Steiner, S. D., \& Watson, M. A. (2006). The service learning component in business education: The values linkage void. Academy of Management Learning \& Education, 5(4), $422-434$.

Stuller, J. (1997). EQ: Edging Toward Respectability. Training, 34(6), 42-45.

Trent, D. M., Grasso, E. T., \& Roby, C. J. (1996). Management education through service-learning. In Proceedings of the International Association for Business and Society Annual Conference, 663-667.

Whetten, D. A., \& Cameron, K. S. (2007). Developing Management Skills ( $7^{\text {th }}$ edition). Reading, MA: Addison-Wesley.

Zlotkowski, E. (1996). Opportunity for all: Linking service-learning and business education. Journal of Business Ethics, 15, 5-19. 